\title{
Palliative EUS-Guided Gallbladder Drainage as a Salvage Treatment of Biliary Obstruction in Inoperable Cholangiocarcinoma
}

\author{
Margarida Flor de Lima Nuno Nunes Carolina Chálim Rebelo \\ Diogo Bernardo Moura José Renato Pereira Maria Antónia Duarte \\ Gastroenterology Department, Hospital do Divino Espírito Santo de Ponta Delgada, Ponta Delgada, Portugal
}

\section{Keywords}

Cholangiocarcinoma Endoscopic ultrasonography ·

Gallbladder drainage

Colecistogastrostomia guiada por ecoendoscopia para drenagem paliativa de obstrução biliar em colangiocarcinoma inoperável

\section{Palavras Chave}

Colangiocarcinoma $\cdot$ Ecoendoscopia $\cdot$ Drenagem da vesícula biliar

A 60-year-old female patient presented with obstructive jaundice and pruritus. Laboratory tests revealed a total bilirubin of $17.23 \mathrm{mg} / \mathrm{dL}$ (direct $14.84 \mathrm{mg} / \mathrm{dL}$ ) and an elevation of CA $19-9$ of 3,820 U/mL. Computed tomography scan showed an infiltrative intrahepatic mass measuring $65 \times 55 \mathrm{~mm}$, involving segment IV, with unclear limits and invasion of the common bile duct. The tumour caused capsule retraction, slight dilation of the intrahepatic bile ducts and marked distention of the gallbladder (Courvoisier sign) (Fig. 1). The reported findings were suggestive of an intrahepatic cholangiocarcinoma, in association with hilar and lumbar-aortic lymph nodes enlargement and peritoneal carcinomatosis. Considering the typical radiological findings and the advanced stage of the disease, no further biopsy was performed.

The case was discussed in a multidisciplinary meeting, in which a palliative biliary drainage was proposed. Endoscopic retrograde cholangiopancreatography was not possible due to failed cannulation. A lack of significant dilation of the common and intrahepatic bile ducts was observed, as well as a marked distention and wall thickening of the gallbladder, which suggested some degree of distal common bile duct obstruction. Considering this later aspect, to provide biliary drainage, and to prevent complications such as cholecystitis or gallbladder perforation, an endoscopic ultrasound (EUS)-guided gallbladder drainage was performed. As shown in Figure 2 and 3, an electrocautery-enhanced lumen-apposing metal stent (LAMS) (Hot AXIOS ${ }^{\mathrm{TM}}, 15 \times 10 \mathrm{~mm}$, Boston Scientific, Marlborough, MA, USA) was placed between the dilated gallbladder and the gastric wall, providing adequate biliary drainage. The freehand technique was employed on stent deployment and no balloon dilation was required. The transgastric approach was chosen because it provid- karger@karger.com www.karger.com/pjg

Karger $\stackrel{\text { ' }}{5}$

BOPEN ACCESS (c) 2021 Sociedade Portuguesa de Gastrenterologia Published by S. Karger AG, Basel

This is an Open Access article licensed under the Creative Commons Attribution-NonCommercial-4.0 International License (CC BY-NC) (http://www.karger.com/Services/OpenAccessLicense), applicable to the online version of the article only. Usage and distribution for commercial purposes requires written permission.
Correspondence to:

Margarida Flor de Lima, margaridaflordelima@ hotmail.com 
Fig. 1. CT scan showed an intrahepatic infiltrative mass (a) with unclear limits, involving segment IV and causing hilar invasion, capsule retraction, slight dilation of the intrahepatic bile ducts and marked distention of the gallbladder (b). a Orange arrows: intrahepatic infiltrative mass causing hilar invasion; blue arrow: capsule retraction. b Orange arrows: intrahepatic infiltrative mass causing hilar invasion; blue arrow: slight dilation of the right intrahepatic bile duct; green arrow: distal common bile duct.
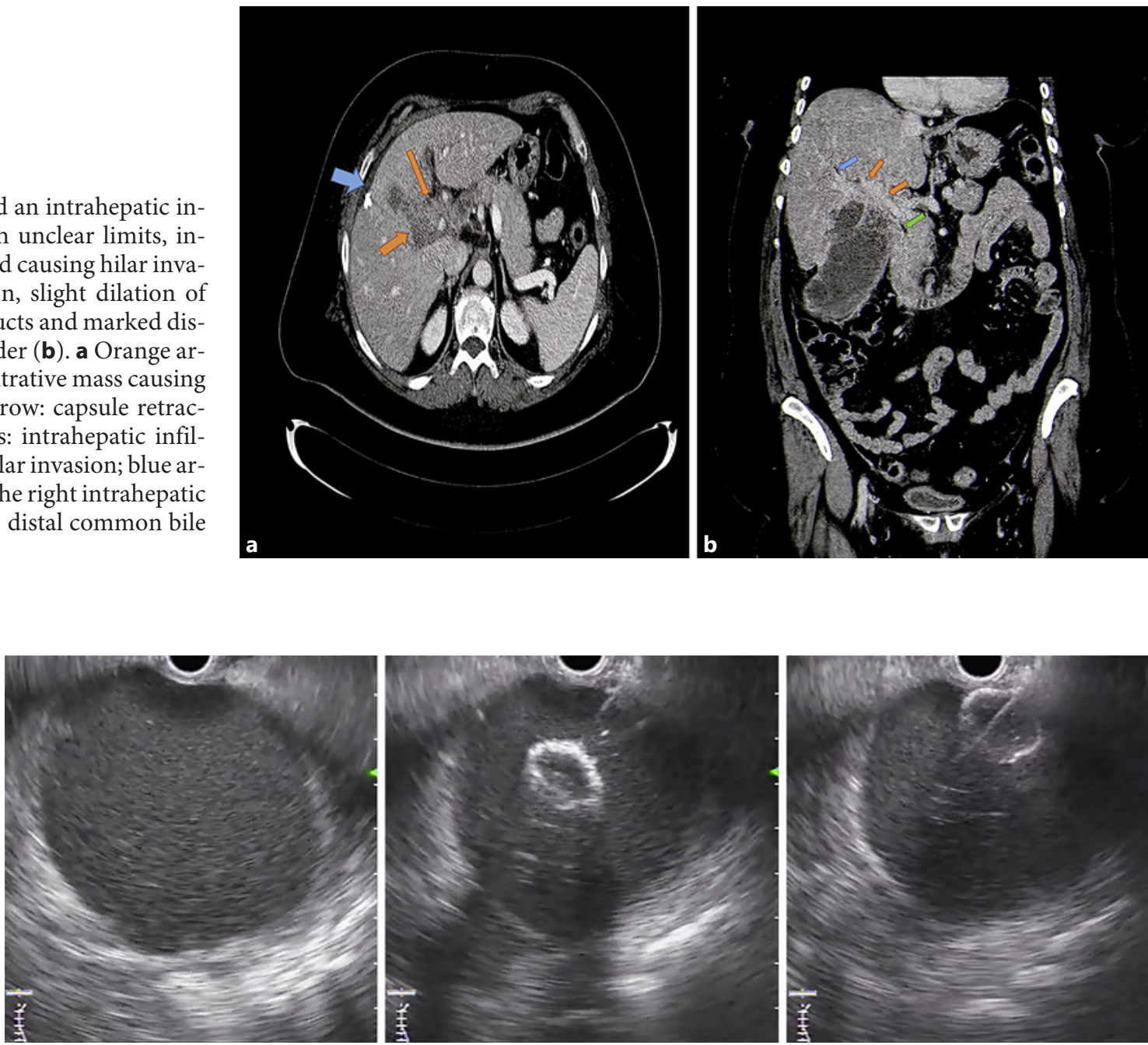

Fig. 2. Ultrasonographic view of LAMS deployment between the dilated gallbladder and the gastric wall.

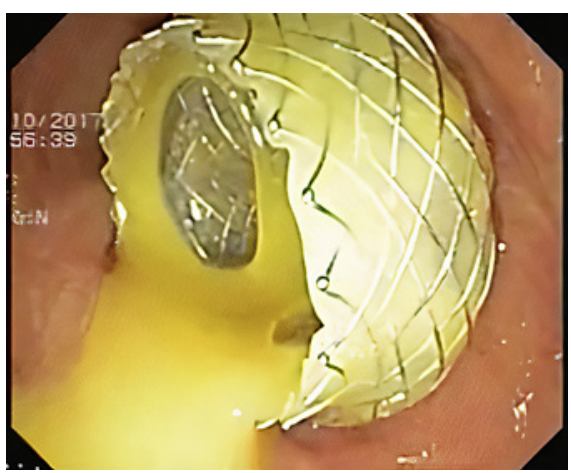

Fig. 3. Endoscopic view of the correctly deployed LAMS with biliary drainage. ed a better apposition between the two surfaces. There were no related immediate or late adverse events. Following the procedure, the patient showed improvement of jaundice and normalization of bilirubin levels in 2 weeks. However, functional status deterioration inhibited further chemotherapy. The patient died 2 months after the procedure without related complications.

Recently, EUS-guided gallbladder stent deployment has emerged as an efficient alternative drainage method to percutaneous or transpapillary gallbladder drainage for patients with acute cholecystitis who are poor surgical candidates [1-3]. Adapted from benign disease, EUSguided gallbladder drainage has also been described as a palliative drainage method in certain cases of malignant biliary obstruction, when other EUS approaches are not feasible, if patency of the cystic duct is assured $[4,5]$. 


\section{Statement of Ethics}

Written informed consent was obtained from the patient. This study did not require review/approval by the appropriate ethics committee.

\section{Conflict of Interest Statement}

The authors have no conflicts of interest to declare.
Funding Sources

None to report.

\section{Author Contributions}

Margarida Flor de Lima: Article concept, literature review, and draft of the manuscript. Nuno Nunes: Main endoscopist of the described procedure. Literature review and critical review of the manuscript. Carolina Chálim Rebelo, Diogo Bernardo Moura, José Renato Pereira and Maria Antónia Duarte: Critical review of the manuscript.

\section{References}

1 Mori Y, Itoi T, Baron TH, Takada T, Strasberg SM, Pitt HA, et al. Tokyo Guidelines 2018: management strategies for gallbladder drainage in patients with acute cholecystitis (with videos). J Hepatobiliary Pancreat Sci. 2018 Jan;25(1):87-95.

2 Mohan BP, Khan SR, Trakroo S, Ponnada S, Jayaraj M, Asokkumar R, et al. Endoscopic ultrasound-guided gallbladder drainage, transpapillary drainage, or percutaneous drainage in high risk acute cholecystitis patients: a systematic review and comparative meta-analysis. Endoscopy. $2020 \mathrm{Feb} ; 52(2): 96-106$.

3 Teoh AY, Kitano M, Itoi T, Pérez-Miranda M, Ogura T, Chan SM, et al. Endosonographyguided gallbladder drainage versus percutaneous cholecystostomy in very high-risk surgical patients with acute cholecystitis: an international randomised multicentre controlled superiority trial (DRAC 1). Gut. 2020 Jun;69(6):1085-91.
4 Law R, Baron TH. Endoscopic UltrasoundGuided Gallbladder Drainage. Gastrointest Endosc Clin N Am. 2018 Apr;28(2):18795.

5 Imai H, Kitano M, Omoto S, Kadosaka K, Kamata K, Miyata T, et al. EUS-guided gallbladder drainage for rescue treatment of malignant distal biliary obstruction after unsuccessful ERCP. Gastrointest Endosc. 2016 Jul;84(1):147-51. 